\title{
KAJIAN PROSES PRODUKSI KATALIS MIKROSFERIK UNTUK PERENGKAHAN MINYAK BUMI DENGAN PENGERING SEMBUR
}

\author{
Aji Hendra Sarosa, Tjokorde Walmiki Samadhi ${ }^{*}$, dan Budiyanto \\ Program Studi Teknik Kimia, Fakultas Teknologi Industri, Institut Teknologi Bandung \\ Jl. Ganesha 10, Bandung 40132 \\ *)Penulis korespondensi : twsamadhi@che.itb.ac.id
}

\begin{abstract}
STUDY OF SPRAY DRYING PROCESS FOR THE PRODUCTION OF PETROLEUM CRACKING CATALYST. Catalyst for the hydrocarbon fluid catalytic cracking $(F C C)$ process consists of zeolite, matrix, fillers, and binders. The FCC catalyst has a microsphere form (10-120 $\mu \mathrm{m})$, and can be produced by spray drying. Operating conditions of spray drying affect the characteristics of the microspheres FCC catalyst. The composition slurry (24\% by weight) is $27 \%$ (by weight) of zeolite NaY, 33\% (by weight) of Belitung kaolin, 20\% (by weight) of silica alumina, 20\% (by weight) of silica sol. The slurry is fed to spray dryer with constant air temperature of $190^{\circ} \mathrm{C}$, ratio of atomizing air flow to slurry feed rate between 0.75:1 to 1:1, hot air flow rate between 0.2-0.3 $\mathrm{m}^{3} / \mathrm{min}$, and slurry feed rate between $15-20 \mathrm{~mL} / \mathrm{min}$. Catalyst particle size distribution produced is in the range of 0.3752-161.1770 $\mu \mathrm{m}$. Angle of repose of the dry product isin the 41.45-49.00 range, which translates to a flowability between passable and poor. Statistical treatment of experimental data by ANOVA method indicates that hot air velocity and interaction between the atomizing air to slurry feed rate ratio and the hot air velocity significantly affect the average particle size. The interaction between the atomizing air to slurry feed ratio with hot air velocity significantly affect particle size distribution as well.
\end{abstract}

Keywords: FCC catalyst; operation conditions; spray drying

\begin{abstract}
Abstrak
Katalis FCC memiliki empat komponen yaitu zeolit, matriks, bahan pengisi, dan bahan pengikat. Katalis FCC berbentuk mikrosfer berukuran 10-120 $\mu$ m. Produksi katalis FCC melibatkan operasi pengering sembur. Kondisi operasi pengering sembur mempengaruhi karakteristik katalis FCC mikrosfer. Campuran slurry (24\% berat) memiliki komposisi 27\% (berat) zeolit NaY, 33\% (berat) kaolin Belitung, $20 \%$ (berat) silika alumina, 20\% (berat) silika sol. Slurry diumpankan ke pengering sembur dengan temperatur udara konstan $190^{\circ} \mathrm{C}$, nisbah antara laju udara atomisasiterhadap laju alir umpan 0,75:1-1:1, laju alir udara panas 0,2-0,3 $\mathrm{m}^{3} / \mathrm{min}$, dan laju umpan masuk 15-20 mL/min. Percobaan menghasilkan distribusi ukuran partikel sebesar 0,3752 $\mu \mathrm{m}$ hingga 161,1770 $\mu \mathrm{m}$. Nilai analisis sudut diam 41,4498 sampai 48,9666, menunjukkan kriteria sifat aliran antara passable dan poor. Pengolahan data percobaan dengan metode ANOVA menunjukkan kecepatan udara panas masuk dan interaksi antara nisbah laju udara atomisasi terhadap laju alir umpan dengan kecepatan udara panas masuk berpengaruh secara signifikan terhadap rata-rata ukuran partikel dan rentang distribusi ukuran katalis FCC.
\end{abstract}

Kata kunci: katalis FCC; kondisi operasi; pengering sembur

How to Cite This Article: Sarosa, A.H., Samadhi, T.W., dan Budiyanto, (2015), Kajian Proses Produksi Katalis Mikrosferik untuk Perengkahan Minyak Bumi dengan Pengering Sembur, Reaktor, 15(4), 241-247, http://dx.doi.org/10.14710/reaktor.15.4.241-247

\section{PENDAHULUAN}

FCC (Fluid Catalytic Cracking) merupakan salah satu unit proses perengkahan yang digunakan dalam pengolahan minyak bumi modern, karena kemampuannya untuk mengkonversi minyak mentah dengan viskositas sangat tinggi serta kadar pengotor 
tinggi menjadi fraksi-fraksi hidrokarbon ringan hingga menengah berkualitas baik. Katalis FCC dengan menggunakan zeolit sebagai komponen aktif mulai diperkenalkan pada awal tahun 1960. Teknologi proses FCC telah berkembang selama 60 tahun terakhir seiring dengan kecenderungan semakin memburuknya kualitas minyak mentah dan semakin ketatnya standar mutu bahan bakar (Meyers, 2004). Kilang-kilang minyak di Indonesia hingga kini praktis masih sepenuhnya mengandalkan katalis FCC yang diimpor, sehingga teknologi produksi katalis ini merupakan hal yang semakin mendesak untuk dikuasai.

Katalis FCC memiliki bentuk serbuk dengan ukuran partikel sekitar $75 \mu \mathrm{m}$ (Sadeghbeigi, 2012) dan distribusi ukuran partikel pada rentang 10-120 $\mu \mathrm{m}$ (Magee dan Mitchell, 1993), dengan geometri partikel mikrosferik, luas permukaan total sebesar 130-370 $\mathrm{m}^{2} / \mathrm{gr}$ dan densitas curah 0,7-0,9 g/mL. Teknologi pengeringan sembur (spray drying) mampu menghasilkan ukuran partikel dan sifat-sifat tersebut (Meyers, 2004).

Katalis FCC modern memiliki empat komponen utama yaitu zeolit, matriks, bahan pengisi (filler), dan bahan pengikat (binder). Zeolit tipe faujasit biasanya digunakan sebagai bahan utama dari katalis perengkahan dengan komposisi $10-50 \%$ dan sisanya adalah komponen lainnya (Magee dan Mitchell, 1993). Zeolit memberikan selektivitas produk dan aktivitas katalitik. Struktur zeolit terdiri dari unit-unit gugus silika dan alumina tetrahedral (piramida) yang terhubung melalui atom oksigen sehingga membentuk jaringan tiga dimensi yang memiliki lorong-lorong antar atom yang panjang (Sadeghbeigi, 2012).

Matriks adalah komponen dari katalis selain dari zeolit yang memiliki aktivitas katalitik atau biasa disebut matriks aktif. Matriks aktif menjaga zeolit agar tidak cepat ternonaktifkan oleh pengotor. Matriks yang efektif harus memiliki struktur berpori yang memungkinkan difusi hidrokarbon ke dalam dan keluar dari katalis. Alumina adalah sumber untuk matriks aktif (Sadeghbeigi, 2012).

Bahan pengisi katalis berfungsi memberikan kekuatan mekanik untuk mengurangi kerusakan katalis di dalam penanganan dan penggunaannya. Untuk katalis FCC, bahan yang sering digunakan sebagai pengisi adalah kaolin. Penambahan kaolin juga dapat meningkatkan densitas tanpa mempengaruhi sifat katalitik dan luas permukaan. Partikel kaolin juga membuat pori-pori besar (Sanden, 2003). Bahan pengikat atau perekat berfungsi menahan zeolit, matriks, pengisi secara bersama-sama. Perekat yang paling umum digunakan adalah silika sol (Sadeghbeigi, 2012).

Pengering sembur menyisihkan cairan dari suspensi atau padatan terdispersi menjadi powder menggunakan atomizing cairan dengan media pemanas (biasanya udara) (Master, 1991). Produk katalis yang dihasilkan memiliki morfologi partikel berupa bulatan dan memiliki kemampuan aliran yang baik sehingga katalis FCC mampu terfluidisasi dengan sempurna dalam unit FCC (Sadeghbeigi, 2012). Jenis alat pengering sembur dan kondisi pengeringan seperti temperatur, laju alir umpan, kecepatan udara panas masukan, dan nisbah laju udara nozzle terhadap laju alir umpan, mempengaruhi karakteristik produk katalis FCC.

Penelitian ini secara khusus mempelajari pengaruh kondisi operasi pengering sembur terhadap karakteristik katalis FCC mikrosfer. Pengaturan kondisi operasi dari pengering sembur terhadap pembuatan mikrosfer katalis FCC diharapkan mampu untuk menghasilkan karakteristik katalis FCC distribusi ukuran partikel 10-120 dengan rata-rata sekitar $75 \mu \mathrm{m}$ dan geometri partikel yang baik, yakni berbentuk mikrosferik.

\section{METODE PENELITIAN Alat dan Bahan}

Bahan baku yang digunakan dalam kajian ini adalah zeolit $\mathrm{NaY}$ (Nisbah $\mathrm{Si} / \mathrm{Al}=3-6$ dengan ukuran pori 7,4 ), kaolin Belitung sebagai bahan pengisi, silika sol sebagai pengikat, dan silika alumina sebagai matriks. Pelarut yang digunakan adalah aqua DM.

Pemakaian kaolin Belitung dimaksudkan untuk memaksimumkan penggunaan bahan-bahan baku yang ada di Indonesia. Secara lebih khusus, keunggulan yang dimiliki oleh kaolin Belitung adalah cadangan kaolin yang besar di wilayah tersebut (Murray, 2007), serta telah terbuktinya kelayakan teknis bahan tersebut untuk produksi katalis FCC (Samadhi dan Nugraha, 2012).

Peralatan utama yang digunakan untuk membuat mikrosfer katalis FCC adalah sebuahunit pengering sembur berskala labtipe ProCepT 4M8-Trix di Laboratorium Teknologi Mineral dan Bahan Anorganik, Program Studi Teknik Kimia ITB. Nosel pada pengering sembur ini termasuk jenis two-fluid nozzle (bi-fluid), yang termasuk ke dalam golongan nosel pneumatik.

\section{Prosedur Pembuatan Katalis}

Formulasi katalis FCC yaitu mengandung campuran $27 \%$ (berat) zeolit Y, 33\% (berat) kaolin Belitung, 20\% (berat) silika alumina, dan 20\% (berat) silika sol. Penentuan ini didasarkan pada penelitian tertutup yang dilakukan sebelumnya. Silika sol dipersiapkan dengan mencampur natrium silikat, air, dan asam sulfat dalam gelas kimia. Silika sol dijaga $\mathrm{pH}$ konstan sekitar pH 3-4. Kaolin Belitung ditambahkan ke dalam sol tersebut secara bertahap dan diaduk perlahan-lahan menggunakan pengaduk magnetik. Zeolit NaY dan silika alumina kemudian ditambahkan ke dalam campuran kaolin-silika sol secara perlahanlahan sambil diaduk selama 1 jam. Campuran tersebut menghasilkan slurry sebanyak $50 \mathrm{ml}$ (Sanden, 2003).

Silika sol dibuat dari larutan natrium silikat 27\%. Larutan tersebut diencerkan ke dalam aqua DM menjadi larutan natrium silikat $12 \%$. Larutan ini diaduk dengan menggunakan pengaduk magnetik. Larutan asam sulfat kemudian ditambahkan secara perlahan-lahan ke dalam larutan natrium sulfat $12 \%$ sehingga membentuk gel pada saat mencapai pH 7. 
Pengadukan dan penambahan asam sulfat dilanjutkan hingga gel berubah kembali menjadi larutan cair,serta dihentikan saat mencapai nilai $\mathrm{pH}$ antara 1,7 dan 2. Silika sol yang dipersiapkan mengikuti reaksisebagai berikut (Zhongdong dkk., 2014):

$$
\begin{gathered}
\mathrm{Si}_{3}^{2-}+2 \mathrm{H}^{+} \Leftrightarrow \mathrm{H}_{2} \mathrm{SiO}_{3} \\
\mathrm{H}_{2} \mathrm{O}+\mathrm{H}_{2} \mathrm{SiO}_{3} \Leftrightarrow \mathrm{Si}(\mathrm{OH})_{2} \\
\mathrm{mSi}(\mathrm{OH})_{4} \rightarrow \mathrm{mSiO}_{2}+2 \mathrm{mH}_{2} \mathrm{O} \\
\mathrm{H}_{2} \mathrm{SiO}_{3} \rightarrow \mathrm{HSiO}_{3}^{-}+\mathrm{H}^{+} \rightarrow \mathrm{SiO}_{3}^{2-}+2 \mathrm{H}^{+} \\
\mathrm{mSiO}_{2}+\mathrm{nSiO}_{3}{ }^{2-}+2 \mathrm{nH}^{+} \rightarrow\left\{\mathrm{m}\left[\mathrm{SiO}_{2}\right] \cdot \mathrm{nSiO}_{3}{ }^{2-} \cdot 2(\mathrm{n}-\mathrm{x}) \mathrm{H}^{+}\right\}^{2 x-} \cdot 2 \mathrm{xH}^{+}
\end{gathered}
$$

Zeolit NaY, kaolin, silika-alumina dimasukkan pelan-pelan dan dijaga pada rentang pH 3 sampai 4. Nilai pH dijaga pada rentang tersebut agar tidak merusak zeolit. Zeolit akan mengalami kerusakan saat pH di bawah 2,8 dan akan kesulitan dengan pengentalan campuran slurry saat $\mathrm{pH}$ di atas 3,5 (Ostermaier dkk., 1976).

Campuran slurry dengan konsentrasi padatan total $24 \%$ berat diumpankan ke alat pengering sembur dengan temperatur udara masuk konstan $190^{\circ} \mathrm{C}$, nisbah antara laju udara atomisasi pada nosel terhadap laju alir umpan 0,75:1-1:1, laju alir udara panas $0,2-0,3 \mathrm{~m}^{3} / \mathrm{min}$, dan laju umpan masuk 15-20 mL/min. Campuran slurry yang berkontak dengan udara panas akan mengering membentuk partikel. Partikel-partikel tersebut akan turun melewati pipa di bagian dasar kolom pengering. Di bagian dasar kolom pengering sembur, partikel tersebut terhembus ke dalam siklon untuk dipisahkan dari udara pengering dan ditampung di dalam botol sampel yang terpasang di dasar siklon.

\section{Rancangan Percobaan}

Percobaan dalam penelitian ini menggunakan rancangan jenis faktorial penuh $2^{\mathrm{k}}$. Rancangan faktorial $2^{\mathrm{k}}$ melibatkan sejumlah $k$ faktor (atau variabel percobaan) yang masing-masing divariasikan pada dua tingkat atau nilai. Rancangan faktorial penuh merupakan jenis rancangan yang efisien untuk percobaan dengan jumlah faktor yang relatif sedikit. Pada rancangan ini, setiap kombinasi dari variabel dan nilai variabel percobaan diuji, sehingga memungkinkan dilakukannya pengukuran efek utama dan efek interaksi secara serempak (Montgomery, 2001). Percobaan dilakukan tanpa replikasi tempuhan karena keterbatasan bahan baku, terutama zeolit $\mathrm{NaY}$.

Kondisi operasi yang akan divariasikan adalah nisbah laju udara atomisasi terhadap laju alir umpan $\left(\mathrm{X}_{1}\right)$, kecepatan udara panas masuk $\left(\mathrm{X}_{2}\right)$, laju alir umpan $\left(\mathrm{X}_{3}\right)$. Pengaturan variabel-variabel operasi sesuai rancangan faktorial penuh $2^{3}$ ini diringkaskan dalam
Tabel 1.

Pengolahan data pada penelitian ini menggunakan uji analisis varian (ANOVA). Metode ini untuk mengetahui signifikansi perbedaan rata-rata antara kelompok sampel satu dengan yang lain.

\section{Metode Analisis}

Karakterisasi produk katalis FCC yang dilakukan dalam kajian ini meliputi:

- Uji distribusi ukuran partikel menggunakan particle size analyzer (PSA) merek Beckman Coulter LS 13 320. Alat ini bekerja dengan difraksi sinar laser untuk menampilkan data mengenai rata-rata diameter partikel.

- Uji morfologi partikel dilaksanakan di fasilitas laboratorium Survei Geologi di Bandung menggunakan scanning electron microscopy (SEM). Uji ini bertujuan mengetahui bentuk (morfologi) dari produk yang terbentuk dari pengering sembur.

- Pengukuran flowability atau kemampuan mengalir dari padatan berwujud serbuk dilakukan menggunakan metode angle of repose (sudut diam) dengan menggunakan basis corong tetap (Hosny dan Alahdal, 2013). Sampel sebanyak 5 gram dijatuhkan melalui corong yang digantung. Sampel tersebut akan menghasilkan tumpukan. Diameter dan ketinggian tumpukan digunakan untuk perhitungan sudut diam menurut persamaan berikut.

$$
\operatorname{Tan} \theta=\frac{\mathrm{h}}{\mathrm{r}}
$$

Di mana $\theta$ adalah sudut diam, $\mathrm{h}$ adalah tinggi tumpukan, dan $\mathrm{r}$ adalah jari-jari tumpukan yang terbentuk.

\section{HASIL DAN PEMBAHASAN \\ Distribusi Ukuran Partikel}

Produk hasil pengeringan sembur menghasilkan butiran atau partikel yang memiliki ukuran bervariasi. Ukuran produk yang bervariasi disajikan dalam distribusi ukuran partikel. Distribusi ukuran partikel untuk setiap sampel produk ditunjukkan pada Gambar 1.

Distribusi ukuran partikel untuk setiap sampel memiliki rentang ukuran yang hampir sama. Partikel hasil pengeringan sembur berada pada rentang 0,3752 $\mu \mathrm{m}$ sampai dengan 161,1770 $\mu \mathrm{m}$. Akan tetapi, setiap sampel memiliki rata-rata ukuran partikel yang berbeda.

Tabel 1. Pengaturan variabel-variabel percobaan

\begin{tabular}{lcc}
\hline \multicolumn{1}{c}{ Variabel } & Nilai rendah $(-)$ & Nilai tinggi $(+)$ \\
\hline nisbah laju udara atomisasi : laju alir umpan $\left(\mathrm{X}_{1}\right)$ & $0,75: 1$ & $1: 1$ \\
kecepatan udara panas masuk $\left(\mathrm{X}_{2}\right)$ & $0,2 \mathrm{~m}^{3} / \mathrm{min}$ & $0,3 \mathrm{~m}^{3} / \mathrm{min}$ \\
laju alir umpan $\left(\mathrm{X}_{3}\right)$ & $15 \mathrm{~mL} / \mathrm{min}$ & $20 \mathrm{~mL} / \mathrm{min}$ \\
\hline
\end{tabular}


Distribusi ukuran partikel ini terlampau lebar dibandingkan hasil produk yang diinginkan. Ukuran partikel yang diinginkan yaitu dalam rentang 10 sampai dengan $120 \mu \mathrm{m}$ (Magee dan Mitchell, 1993).

Produk dengan PC24_8 memiliki profil distribusi ukuran partikel yang berbeda dengan yang lain. Perbedaan profil pada produk PC24_8 menunjukkan terjadinya aglomerasi. Pengaturan pengadukan yang dilakukan mempengaruhi terjadinya aglomerasi sampai terjadinya bulatan partikel (Perez, dkk., 2007). Gambar 1 juga menunjukkan bahwa PC24_8 memiliki bentuk distribusi ukuran partikel yang bimodal artinya memiliki dua puncak, hal itu karena sampel mempunyai dua populasi berbeda yang terbentuk.

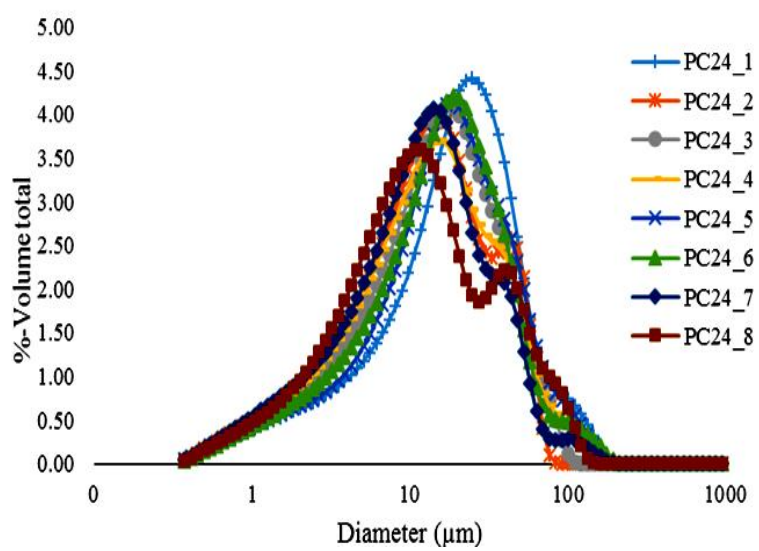

Gambar 1. Distribusi ukuran partikel pada berbagai kondisi operasi pengering sembur.

\section{Pengaruh Kondisi Operasi terhadap Rata-rata Ukuran Partikel (Mean)}

Hasil analisis rata-rata ukuran partikel tersebut diolah menggunakan metode ANOVA. Pendekatan analisis percobaan menggunakan tingkat keberartian $(\alpha)$ sebesar 0,1 . Nilai tingkat keberartian $(\alpha)$ sebesar 0,1 dipilih karena jumlah sampel yang sedikit dan ketiadaan replikasi tempuhan dalam percobaan ini. Hasil rata-rata ukuran diameter partikel untuk setiap sampel bisa dilihat pada Tabel 2.

Rata-rata ukuran partikel pada Tabel 2 diolah datanya. Hasil pengolahan data digunakan untuk mengetahui pengaruh dari kondisi operasi pengering sembur terhadap rata-rata ukuran partikel yang dihasilkan. Hasil yang diperoleh belum baik dibandingkan dengan spesifikasi rata-rata ukuran partikel katalis FCC komersial yaitu sekitar $75 \mu \mathrm{m}$ (Sadeghbeigi, 2012). Perbandingan nisbah laju udara atomisasi dengan laju alir umpan dan temperatur udara panas masukan mempengaruhi rata-rata ukuran partikel (Masters, 1991). Akan tetapi dalam penelitian ini temperatur yang digunakan tidak cukup mampu untuk menaikkan rata-rata distribusi ukuran partikel. Penelitian yang lain menggunakan temperatur udara masukan yang lebih tinggi sekitar $220-357^{\circ} \mathrm{C}$ (Sanden, 2003).

Pengolahan data rata-rata ukuran partikel dilakukan mengikuti prinsip hierarki. Prinsip hierarki ini digunakan untuk membantu menentukan variabelvariabel proses dan interaksi antar variabel yang mungkin berpengaruh secara signifikan (Montgomery, 2001).

Tabel 2. Hasil rata-rata ukuran partikel

\begin{tabular}{ccc}
\hline No & Kode & $\begin{array}{c}\text { Rata-rata ukuran partikel, mean } \\
(\mu \mathrm{m})\end{array}$ \\
\hline 1 & PC24_1 & 27,58 \\
2 & PC24_2 & 18,38 \\
3 & PC24_3 & 20,32 \\
4 & PC24_4 & 21,14 \\
5 & PC24_5 & 25,15 \\
6 & PC24_6 & 23,21 \\
7 & PC24_7 & 18,40 \\
8 & PC24_8 & 20,46 \\
\hline
\end{tabular}

Hasil pengolahan data dengan menggunakan metode ANOVA untuk rata-rata ukuran partikel pada berbagai kondisi operasi dapat dilihat pada Tabel 3.

Tabel 3. Rangkuman hasil pengolahan data dengan

\begin{tabular}{lccc}
\multicolumn{4}{c}{ ANOVA } \\
\hline \multicolumn{1}{c}{ Source } & Efek & Koef & Nilai P \\
\hline Constant & & 30,38 & \\
Ratio $\left(\mathrm{X}_{1}\right)$ & $-2,065$ & $-9,793$ & 0,226 \\
Heat flow $\left(\mathrm{X}_{2}\right)$ & $-3,500$ & $-35,00$ & 0,073 \\
Interaction $\mathrm{X}_{1} \cdot \mathrm{X}_{2}$ & 3,505 & 35,05 & 0,072 \\
\hline
\end{tabular}

Hasil ANOVA menunjukkan bahwa nilai $\mathrm{P}$ faktor kecepatan udara panas masuk sebesar 0,073 dan interaksi antara nisbah laju udara atomisasi terhadap laju alir umpan dengan kecepatan udara panas masuk sebesar 0,072. Oleh karena itu dapat disimpulkan bahwa variabel untuk kecepatan udara panas masuk dan interaksi antara nisbah laju udara atomisasi terhadap laju alir umpan dengan kecepatan udara panas masuk merupakan variabel operasi yang berpengaruh secara signifikan.

Persamaan regresi model faktorial penuh dinyatakan:

$$
Y=30,58-9,795 X_{1}-35 X_{2}+35,05 X_{1} X_{2}
$$

Semakin tinggi kecepatan udara panas yang diberikan akan menurunkan rata-rata ukuran partikel. Udara panas menyediakan panas untuk pengeringan, mengontrol perjalanan partikel selama pengeringan dan menghilangkan kelembapan uap secara cepat menjauh dari zona atomisasi (Master, 1991).

Kenaikan kecepatan udara panas akan meningkatkan kecepatan evaporasi, tetapi tidak secara signifikan, karena energi tidak digunakan secara efektif di dalam ruang pengeringan. Energi panas tersebut akan terbuang keluar ke lingkungan. Waktu tinggal partikel berkurang pada kecepatan udara panas yang lebih tinggi yang menghasilkan penurunan laju pengeringan volumetrik keseluruhan (Huang dkk., 2004).

Nisbah laju udara atomisasi terhadap laju alir umpan pada percobaan ini juga berpengaruh terhadap rata-rata ukuran partikel, meskipun tidak secara signifikan. Semakin besar nisbah laju udara atomisasi 
terhadap laju alir umpan maka akan semakin kecil rata-rata ukuran partikel yang diperoleh. Laju udara atomisasi dengan laju alir umpan memiliki suatu korelasi yang dapat dituliskan (Master, 1991):

$$
\mathrm{D}=\frac{\mathrm{A}}{\left(\mathrm{v}_{\text {rel }}^{2} \rho_{\mathrm{a}}\right)^{2}}+\mathrm{B}\left(\frac{\mathrm{M}_{\text {air }}}{\mathrm{M}_{\text {liq }}}\right)^{-\beta}
$$

Dimana, $\mathrm{V}_{\text {rel }}$ kecepatan relatif antara udara dan cairan pada kepala nosel, $\mathrm{M}_{\mathrm{air}} / \mathrm{M}_{\mathrm{liq}}$ nisbah massa antara udara terhadap cairan, eksponen $\alpha$ dan $\beta$ fungsi dari model nosel, dan A,B konstanta antara model nosel dan sifat cairan.

Interaksi antara kecepatan udara panas masuk dengan nisbah laju udara atomisasi terhadap laju alir umpan juga mempunyai pengaruh secara signifikan. Perkalian antara kecepatan udara panas masuk dengan nisbah laju udara atomisasi terhadap laju alir umpan berpengaruh positif artinya semakin besar perkalian antara keduanya akan meningkatkan rata-rata ukuran partikel.

\section{Pengaruh Kondisi Operasi terhadap Distribusi Ukuran Partikel}

Lebar distribusi ukuran partikel dicirikan oleh perbedaan antara ukuran persentil ke-10 $\left(\mathrm{d}_{10}\right)$ dan persentil ke-90 $\left(\mathrm{d}_{90}\right)$ berdasarkan volume kumulatif partikel yang lebih kecil dari persentil tersebut. Pengukuran rentang distribusi partikel biasa dihitung dengan (Bakker, 1988):

$$
\text { Log span }=\log \left(\frac{d_{90}}{d_{10}}\right)
$$

Distribusi ukuran partikel dan densitas pada katalis FCC sangat penting dalam sifat-sifat fluidisasi dan pemisahan katalis dari aliran produk. Partikelpartikel kecil sangat tidak diinginkan karena akan menyebabkan kerugian dalam unit FCC (Sanden, 2003). Nilai $\mathrm{d}_{10}$, median $\left(\mathrm{d}_{50}\right), \mathrm{d}_{90}$ dan log span tersaji dalam Tabel 4.

Hasil ANOVA menunjukkan bahwa nilai $\mathrm{P}$ faktor untuk interaksi antara nisbah laju laju udara atomisasi terhadap alir umpan dengan kecepatan udara panas masuk sebesar 0,099. Oleh karena itu dapat disimpulkan bahwa interaksi antara nisbah laju udara atomisasi terhadap laju alir umpan dengan kecepatan udara panas masuk merupakan variabel operasi yang berpengaruh secara signifikan.

Hasil pengolahan data dengan menggunakan metode ANOVA untuk nilai log span pada berbagai kondisi operasi dapat dilihat pada Tabel 5.

Tabel 4. Nilai ukuran partikel saat $\mathrm{d}_{10}, \mathrm{~d}_{50}, \mathrm{~d}_{90}$ dan nilai

\begin{tabular}{cccccc}
\multicolumn{7}{c}{ log span } \\
\hline No & Kode & $\mathrm{d}_{10}$ & $\mathrm{~d}_{50}$ & $\mathrm{~d}_{90}$ & log span \\
\hline 1 & PC24_1 & 3,49 & 20,86 & 56,94 & 1,212 \\
2 & PC24_2 & 2,61 & 13,46 & 44,05 & 1,228 \\
3 & PC24_3 & 2,87 & 15,28 & 45,36 & 1,199 \\
4 & PC24_4 & 2,67 & 13,93 & 48,14 & 1,256 \\
5 & PC24_5 & 3,15 & 17,77 & 55,10 & 1,244 \\
6 & PC24_6 & 3,04 & 16,63 & 47,97 & 1,198 \\
7 & PC24_7 & 2,42 & 12,55 & 41,45 & 1,234 \\
8 & PC24_8 & 2,58 & 11,77 & 51,82 & 1,303 \\
\hline
\end{tabular}

Tabel 5. Rangkuman hasil pengolahan data dengan

\begin{tabular}{lccc}
\multicolumn{4}{c}{ ANOVA } \\
\hline \multicolumn{1}{c}{ Source } & Efek & Koef & Nilai P \\
\hline Constant & & 1,165 & \\
Ratio $\left(\mathrm{X}_{1}\right)$ & 0,024 & $-0,085$ & 0,254 \\
Heat flow $\left(\mathrm{X}_{2}\right)$ & 0,028 & 0,278 & 0,200 \\
Interaction $\mathrm{X}_{1} \cdot \mathrm{X}_{2}$ & 0,039 & 0,388 & 0,099 \\
\hline
\end{tabular}

Persamaan regresi model faktorial penuh dinyatakan:

$$
\mathrm{Y}=1,165-0,085 \mathrm{X}_{1}+0,278 \mathrm{X}_{2}+0,388 \mathrm{X}_{1} \mathrm{X}_{2}
$$

Pengaruh interaksi antara nisbah laju udara nozzle terhadap laju alir umpan dengan kecepatan udara panas masuk sangat signifikan dalam mengatur rentang dari distribusi ukuran partikel. Semakin besar interaksi antara keduanya akan meningkatkan rentang distribusi ukuran partikel. Rentang distribusi ukuran partikel pada percobaan ini masih terlalu besar dibandingkan dengan penelitian yang dilakukan oleh Sanden (2003). Distribusi ukuran partikel pada penelitian tersebut memiliki rentang yang sempit. Nilai log span penelitian yang dilakukan Sanden (2003) untuk distribusi ukuran partikel pada tekanan 26 bar dan 39 bar sekitar 0,3657-0,3689 (Sanden, 2003).

\section{Morfologi Katalis FCC}

Katalis FCC percobaan sudah memiliki bentuk yang bulat. Akan tetapi, perbedaan morfologi katalis FCC percobaan dengan katalis komersial terlihat jelas. Perbandingan kedua katalis ditunjukkan pada Gambar 2. Permukaan katalis FCC percobaan setelah pengeringan sembur memiliki permukaan yang kurang halus dibandingkan dengan katalis komersial, selain itu masih banyak aglomerat yang terbentuk.

Temperatur yang kurang tinggi menyebabkan fluks pengeringan yang rendah sehingga permukaan partikel yang masih lengket. Partikel-partikel yang masih lengket tersebut saling bertabrakan ataupun menabrak dinding ruang pengering dan menyebabkan terbentuknya aglomerat.

Campuran slurry yang diumpankan ke dalam ruangan pemanas terpecah menjadi droplet-droplet yang lebih kecil oleh kompresi udara. Droplet-droplet tersebut segera menyusut karena adanya penguapan air dalam slurry oleh udara pemanas. Selama proses pengeringan, uap dari dalam droplet bergerak ke luar. Difusi uap di dalam droplet berlangsung tidak seragam menyebabkan pengeringan yang tidak seragam (Sanden dkk., 2004).

Penyusunan silika sol mempunyai pengaruh terhadap kinetika pengeringan. Silika dan katalis FCC tidak menyusut seragam selama pengeringan, adanya lapisan retak yang menghasilkan banyak pulau-pulau kecil. Perilaku polimerisasi silika adalah fenomena yang kompleks karena melibatkan banyak reaksi (Sanden dkk., 2004).

Pencampuran sempurna dari berbagai komponen katalis FCC diperlukan untuk menghasilkan katalis yang keras, padat, dan homogen. 
Konsekuensi dari pencampuran yang kurang sempurna adalah ketahanan gesekan yang buruk dan densitas serta morfologi partikel yang buruk pula (Magee dan Mitchell, 1993). Morfologi partikel yang terbentuk bisa berupa permukaan yang kasar, partikel tidak berbentuk bulatan, dan terbentuknya aglomerat.

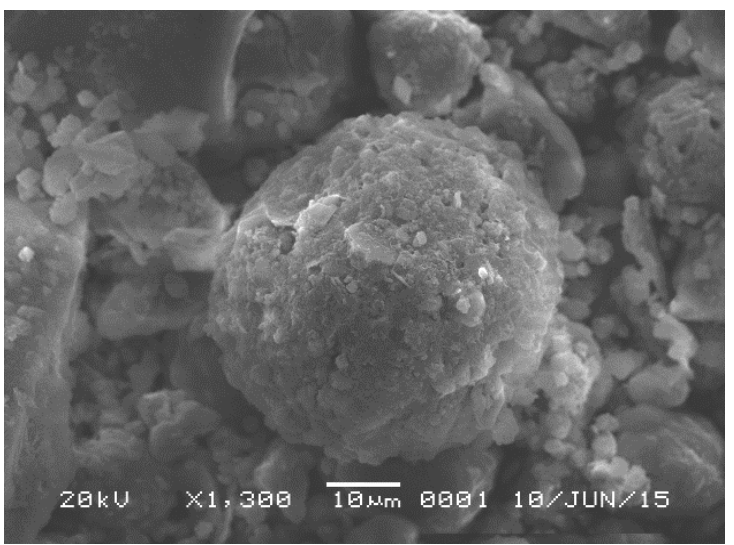

(a)

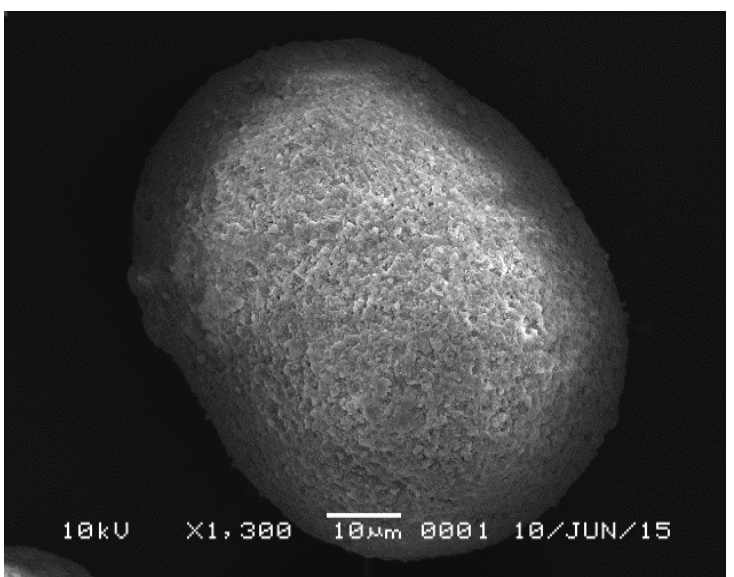

(b)

Gambar 2. Hasil analisis SEM : (a) katalis FCC percobaan sampel PC24_3; (b) katalis komersial

\section{Flowability Katalis FCC}

Analisis flowability dilakukan terhadap dua sampel, yaitu katalis FCC setelah pengeringan sembur (tanpa pengeringan lanjut) dan katalis FCC dengan pengeringan lanjut. Hasil analisis flowability tersaji dalam Tabel 6.

Tabel6.Sudut diam untuk katalis FCC

\begin{tabular}{cccc}
\hline No & Kode & $\begin{array}{c}\text { Sudut diam } \\
\text { (tanpa } \\
\text { pengeringan } \\
\text { lanjut) }\end{array}$ & $\begin{array}{c}\text { Sudut diam } \\
\text { (dengan } \\
\text { pengeringan } \\
\text { lanjut) }\end{array}$ \\
\hline 1 & PC24_1 & 45,1539 & 33,1103 \\
2 & PC24_2 & 43,8310 & 34,3497 \\
3 & PC24_3 & 41,4498 & 37,6233 \\
4 & PC24_4 & 45,9802 & 35,3767 \\
5 & PC24_5 & 48,9666 & 36,1300 \\
6 & PC24_6 & 48,5220 & 41,6720 \\
7 & PC24_7 & 44,3394 & 38,5683 \\
8 & PC24_8 & 44,5900 & 35,7513 \\
\hline
\end{tabular}

Kriteria empiris antara sifat aliran dengan hasil yang diperoleh dari tes partikel tersaji dalam Tabel 7.

Tabel 7. Hubungan empirik antara sifat aliran dengan

\begin{tabular}{cc} 
hasil tes yang diperoleh (Lumay dkk., 2012) \\
\hline Sifat aliran & Sudut diam \\
\hline Excellent & $20-30$ \\
Good & $31-35$ \\
Fair & $36-40$ \\
Passable & $41-45$ \\
Poor & $46-55$ \\
Very poor & $56-65$ \\
Very very poor & $>65$ \\
\hline
\end{tabular}

Katalis FCC tanpa pengeringan lanjut memiliki nilai sudut diam antara 41,4498 sampai 48,9666, nilai mengindikasikan bahwa katalis FCC memiliki kriteria sifat aliran antara passable dan poor. Katalis FCC sesudah mengalami pengeringan lanjut memiliki nilai sudut diam antara 33,1103 dan 41,6720 yang berarti kriteria sifat aliran antara good dan fair (Lumay dkk., 2012).

Perbedaan flowability dari kedua partikel tersebut kemungkinan disebabkan oleh adanya gaya kohesif yang terjadi dengan adanya jembatan cairan. Sudut diam dan sudut mengalir juga berubah seiring adanya gaya kohesi. Selain itu, kohesi menyebabkan beberapa fluktuasi aliran dan beberapa penyimpangan pada permukaan tumpukan (Lumay dkk., 2012).

Perbedaan ini juga terjadi karena masih adanya molekul air dalam partikel yang menyebabkan adanya ikatan hidrogen. Ikatan ini memiliki daya tarik menarik antar molekul yang kuat, sehingga mempengaruhi kemampuan mengalir dari katalis FCC tersebut. Kadar air sisa sebesar 4,6-6,4\%.

Penggunaan temperatur tinggi dalam pengeringan sembur membantu meningkatkan flowability dari partikel. Temperatur tinggi membatu menghilangkan sisa air yang terdapat dalam partikel katalis.

\section{Pengaruh Kondisi Operasi terhadap Flowability}

Hasil pengolahan data dengan menggunakan metode ANOVA untuk nilai sudut diam katalis FCC tanpa pengeringan lanjut pada berbagai kondisi operasi dapat dilihat pada Tabel 8.

Tabel 8. Rangkuman hasil pengolahan data dengan

\begin{tabular}{lccc}
\multicolumn{4}{c}{ ANOVA } \\
\hline \multicolumn{1}{c}{ Source } & Efek & Koef & Nilai P \\
\hline Constant & & 12,279 & \\
Heat flow $\left(\mathrm{X}_{2}\right)$ & $-2,529$ & 97,290 & 0,100 \\
Umpan $\left(\mathrm{X}_{3}\right)$ & 2,501 & 2,251 & 0,103 \\
Interaction $\mathrm{X}_{2} \cdot \mathrm{X}_{3}$ & $-1,751$ & $-7,004$ & 0,214 \\
\hline
\end{tabular}

Hasil ANOVA tersebut menunjukkan bahwa nilai $\mathrm{P}$ faktor untuk kecepatan udara masuk sebesar 0,100 yang sama dengan nilai keberartian $(\alpha)$ sebesar 0,1 . Oleh karena itu dapat disimpulkan bahwa kecepatan udara masuk merupakan variabel operasi yang berpengaruh secara signifikan dalam analisis percobaan ini. 

dinyatakan:

Persamaan regresi model faktorial penuh

$$
Y=12,279+97,29 X_{2}+2,2519 X_{3}-7,005 X_{2} X_{3}(6)
$$

Pengaruh kecepatan udara panas masuk signifikan dalam mengatur kemampuan mengalir (flowability) katalis FCC. Semakin besar kecepatan udara panas masuk akan meningkatkan sudut diam dari katalis FCC, sehingga akan menurunkan kemampuan mengalir dari katalis FCC tersebut. Nilai konstanta yang besar dari kecepatan udara panas masuk menunjukkan bahwa kenaikan kecepatan udara panas yang kecil menyebabkan perubahan yang besar terhadap sudut diam.

\section{KESIMPULAN}

Distribusi ukuran partikel untuk setiap sampel memiliki rentang antara $0,3752 \mu \mathrm{m}$ hingga 161,1770 $\mu \mathrm{m}$. Variabel operasi yang berpengaruh secara signifikan terhadap rata-rata ukuran partikel katalis FCC dan log span adalah kecepatan udara panas masuk dan interaksi antara nisbah laju udara nozzle terhadap laju alir umpan dengan kecepatan udara panas masuk.

Kecepatan udara panas yang diperbesar akan menurunkan rata-rata ukuran partikel dan memperlebar rentang distribusi. Semakin besar nisbah laju udara nozzle terhadap laju alir umpan maka akan semakin kecil rata-rata ukuran partikel yang diperoleh.

Pembuatan silika sol, temperatur yang kurang tinggi, dan pengadukan yang kurang sempurna menyebabkan morfologi permukaan partikel katalis FCC yang buruk.

Analisis sudut diam mendapatkan nilai 41,4498 sampai 48,9666, hal ini menunjukkan bahwa katalis FCC tersebut memiliki kriteria sifat aliran antara passable dan poor, hal ini diduga disebabkan oleh adanya gaya kohesif dan kadar air sisa dalam produk.

\section{DAFTAR PUSTAKA}

Bakker, H.H.C., (1988), Control of particle size distributions in spray dryer at two-fluid nozzles, $A$ thesis of Doctor of Philosophy in Chemical Engineering in the University of Canterbury, New Zealand.

Hosny, K.M. and Alahdal, A.M., (2013), Utilization of solid dispersion technique to improve solubility and flowability of acyclovir, Life Science Journal, 10(4), pp. 40-44.

Huang, L., Kumar, K., and Mujumdar, A.S., (2004), Spray evaporation of different liquids in a drying chamber-effect on flow, heat, and mass transfer performances, Chinese J. Chem. Eng.,12(6), pp.737743.
Lumay, G., Boschini, F., Traina, K., Bontempi, S., Remy, J.C., Cloots, R., and Vandelwalle, N., (2012), Measuring the flowing properties of powders and grains, Powder Technology, 224, pp. 19-27.

Magee, J.S. and Mitchell, M.M, Jr., (1993), Fluid catalytic cracking: science and technology, Elsevier: Amsterdam, The Netherlands.

Masters, K., (1991), Spray drying handbook, Fifth Edition, John Wiley \& Sons, Inc., United States of America.

Meyers, R.A., (2004), Handbook of petroleum refining processes, Third Edition, McGraw-Hill, United States of America.

Montgomery, D.C., (2001), Design and analysis of experiments, Fifth Edition, John Wiley \& Sons, Inc., United States of America.

Murray, H.H., (2007), Applied clay mineralogy: occurrences, processing and application of kaolins, bentonites, palygorskite-sepiolite, and common clays, First Edition, Elsevier, Amsterdam, The Netherlands.

Perez, P.G., Pagnoux, C., Pringuet, A., Videcoq, A., and Baumard, J.F., (2007), Agglomeration of alumina submicronparticles by silica nanoparticle: application to processing sphere by colloidal route, Journal of Colloid and Interface Science, 313, pp. 527-536.

Sadeghbeigi, R., (2012), Fluid catalytic cracking handbook, Third Edition, Butterwoth-Heinemann. USA, Chapter 3-4.

Samadhi, T.W. dan Nugraha, F.E., (2012), Rekayasa mikrosfer zeolit sebagai penyangga katalis FCC dengan bahan baku mineral kaolin, Jurnal Teknik Kimia Indonesia, 11(3), pp. 149-158.

Sanden, S.C.T van der., (2003), A fundamental study of spray drying fcc catalyst, Desertation, Eindhoven: Technische Universiteit Eindhoven, Belanda, pp. 4583.

Sanden, S.C.T van der., Coumans, W.J., and Kerkhof, P.J.A.M., (2004), The drying behaviour of multicomponent fluid catalytic cracking catalyst, Proceedings of the 14th International Drying Symposium (IDS 2004), São Paulo, Brazil, vol. B, pp. 1089-1096.

Zhongdong, Z., Zhaoyong, L., Zifeng, Y., Yi, W., Haitao, Z., and Zhifeng, W., (2014), Research on new silica sol matrix used in fluid catalytic cracking reaction, China Petroleum Processing Ana Petrochemical Technology 2014, 16(2), pp 29-33. 